\title{
Returning to the Religion of Abraham: Controversies over the Gafatar Movement in Contemporary Indonesia
}

\section{Al Makin}

To cite this article: Al Makin (2019) Returning to the Religion of Abraham: Controversies over the Gafatar Movement in Contemporary Indonesia, Islam and Christian-Muslim Relations, 30:1, 87-104, DOI: 10.1080/09596410.2019.1570425

To link to this article: https://doi.org/10.1080/09596410.2019.1570425

曲 Published online: 05 Feb 2019.

Submit your article to this journal $\widetilde{ }$

Lلll Article views: 103

View Crossmark data $\complement$ 


\title{
Returning to the Religion of Abraham: Controversies over the Gafatar Movement in Contemporary Indonesia
}

\author{
Al Makin \\ Sociology of Religion, Sunan Kalijaga State Islamic University, Yogyakarta, Indonesia
}

\begin{abstract}
This article explores the idea of 'Milah Abraham', a term used and advocated by Ahmad Mushaddeq and Mahful Muis, the founders of Gafatar (Gerakan Fajar Nusantara/Archipelagic Dawn Movement). Mahful Muis, a prominent companion of Mushaddeq, has written many works about the idea of the religion of Abraham. This article answers the questions of how the idea of Milah Abraham emerged, and what are the implications of its emergence in the context of plural Indonesian Islam. Based on interviews and the written works of both Gafatar leaders, this study explores the idea of the religion of Abraham and how it can go beyond Judaism, Christianity and Islam to a new spirituality that combines the three religious traditions. The idea of Milah Abraham not only offers a new syncretism in the context of plural Indonesian Islam, but also challenges the establishment of Islamic orthodoxy in the country. Since the 1970s, the idea of returning to the religion of Abraham has contributed to the discussion of pluralism among many Indonesian Muslim intellectuals.
\end{abstract}

\section{ARTICLE HISTORY}

Received 18 January 2018

Accepted 12 January 2019

\section{KEYWORDS}

New religious movement; pluralism; religion of Abraham; Ahmad Mushaddeq; Gafatar; Mahful Muis; Islam in Indonesia

\section{Introduction}

The archipelago of Indonesia is home to a Muslim majority population. However, the way Islam is practised there has been deeply affected by a complex and dynamic history of cultural diversity, which distinguishes Indonesian Islam from Islam in other parts of the world (Geertz 1968; Ricklefs 1981, 2006, 2007; Hefner 1985; Woodward 2011, 1989; Makin 2016c). Historians, sociologists and anthropologists have documented the uniqueness of Islam in Indonesia, where the integration of religion with diverse local cultures creates unique and diverse Islamic practices, as is seen in rituals, social movements and styles of architecture. The authoritarian Suharto regime, commonly known as the 'New Order', fell in 1998, and was followed by the 'reform period' (masa reformasi), when the diversity of Indonesian Islam entered a new phase in which the country has faced a growing phenomenon of religious orthodoxy and conservatism. ${ }^{1}$ Some conservative Islamic ideologies that were silenced by Suharto during his 32 years in power gained popularity during the open era of democratization (Fealy 2004; Hefner 2010, 2008; Feillard and Madinier 2011; Makin 2015, 2016b, 2016e, 2017a).

During Indonesia's political and economic crisis in 1998, many Indonesians claimed to have received divine messages and attracted a considerable number of followers with 
whom the claimants to prophethood have formed religious groups (Makin 2016a, 2017b, 2010). These movements can be classified as New Religious Movements (NRMs), some of which have also emerged in the more secularized societies of Europe, America and Asia (Barker 1999; McDaniel 2010), where religion is privatized, in response to modernization and globalization. These NRMs offer an alternative spirituality to people in Europe and America, where the role of public religion has been assumed to be in decline (Dawson 1998a, 1998b; Mayer 2011). However, the assumption that the role of religion would decline in our twenty-first century globalized world has been questioned. In many Muslim countries, it is common to display religious piety in public and religion is experiencing a resurgence in politics (Hefner 2008, 2010). Peter Berger (2008) is perhaps right in coining the word 'desecularization' to refer to the resurgence of religion in the twenty-first century. All in all, the NRMs in the Indonesian Muslim community came into being as a response to, and critique of, the hegemonic process of Islamization, in which Islamic orthodoxy gained authority in the public domain. Scholarly discussion of NRMs in Indonesia is still rare (McDaniel 2010; Makin 2016a), particularly discussions focusing on the new developments in Islamic religiosity during Indonesia's reform period.

During this reform period, two opposing movements emerged: radical and conservative Islamic groups and NRMs. While the radicals intended to universalize their truth claims by returning to the literal reading of Islamic sources - the Qur'an and Sunna (traditions of the Prophet) - and absolutist Islamic religiosity (Makin 2017a), the NRMs wanted to create a new spirituality and religiosity that combined divergent religious teachings such as Islam, Christianity, Judaism, Buddhism, Hinduism and local traditions. However, the radical groups accused the NRMs of deviating from true Islam (Arifin 2008; Hosen 2012; Burhani 2014; Fenwick 2014), and the NRMs responded by criticizing both Islam and radicals. Lia Eden, for instance, has criticized the practice of radical and conservative Islam in Indonesia, claiming that it is problematic (Makin 2016a).

After the collapse of the New Order, in the midst of a political and economic crisis, many NRMs became millenarian or Mahdist, offering salvation and promising to salvage Indonesian society from an imminent doomsday. The Qiyadah Islamiyah, founded by Ahmad Mushaddeq and Mahful Muis, and which later become Komar (Komunitas Milah Abaraham/Abrahamic Religion Community) and Gafatar (Gerakan Fajar Nusantara/Archipelagic Dawn Movement), was this type of NRM. The Gafatar promised the renewal of Islamic religious tradition in Indonesia via Mushaddeq's claim to be a prophet and Messiah who would save Indonesia and Muslims from destruction. However, the prophetic claim not only sparked controversy but also challenged Islamic orthodoxy as understood by the Ulama Council of Indonesia (Majelis Ulama Indonesia; MUI) and the MUI received support from the government to prosecute the movement's leaders. In 2008, Mushaddeq was brought to court, tried and jailed.

This article examines the works and actions of both Mushaddeq and Mahful Muis, the founders of the Gafatar group or Qiyadah Islamiyah. The former counts as the founding father, while the latter nurtures the ideology and serves as an intellectual resource for Mushaddeq and the group. Mushaddeq's charisma has led many Indonesians to join his group and believe in his prophethood. He is a talented organizer and uses his oratorical skills to keep the faith of the members united, speaking eloquently and convincingly to group members. Mahful, on the other hand, uses his knowledge of both classical and modern Arabic sources to write about the group's ideology. Oftentimes, Mushaddeq 
dictates ideas and Mahful refines them and sets them down in writing. Their collaboration has produced some innovative ideas, chief among them being 'Milah Abraham', a term they themselves chose and which they use to call upon their followers to return to the religion of Abraham, the forefather of Judaism, Christianity and Islam. Two of the questions this article considers are: How did the idea of Milah Abraham emerge? And what are the implications of its emergence in the context of the pluralistic Islam of Indonesia? To answer these questions, the article will present the biographies of the two leaders of the movement and discuss the movement's development to become the Gafatar. It will shed light on the movement's core idea, Milah Abraham, and show how this idea can contribute to the discussion of pluralism in an Indonesian context. ${ }^{2}$

\section{Two leading proponents of Milah Abraham}

Ahmad Mushaddeq, whose original name is Abdussalam, was born on 21 April 1944 in Jakarta and received his education there. He finished elementary school in 1957, teacher training (SGA/Sekolah Guru A) in 1960, and higher level teacher training (SGB/Sekolah Guru B) in 1963. Mushaddeq has been interested in both sports and religion since his youth. In 1971, he graduated from the Sports Academy (STO/Sekolah Tinggi Olah Raga) with a final assignment paper on badminton and was then employed as a civil servant in the Ministry of Sport (1971-1999). His most notable sporting achievement was as a national badminton coach in 1990-1994. An indication of Mushaddeq's interest in religion is his membership of HUDA (Himpunan Usaha Dakwah/Association of Islamic Call), which he headed from 1984 to 1987. Between 1987 and 1997, Mushaddeq was active in an Islamist organization called NII (Negara Islam Indonesia/Islamic State of Indonesia), serving as a recruiter (mudabbir/Koordinator Wilayah) for Region 9. The aim of NII was to establish an Islamic state in Indonesia (Muis, Abdussalam, and Cahya 2017b, 3). Mushaddeq has two wives. With the first wife, Waginem, he has four children, and with the second, Michela Chika Ananda, he has a daughter.

Mushaddeq's career as a badminton coach gave him economic success but he was always curious about religious matters. He consulted many religious leaders, but the rabbis, Christian priests and Islamic scholars all disappointed him. The leader of NII, Panji Gumilang, also failed to satisfy his thirst for religious knowledge, so he left the organization. Eventually, he sought his own way to satisfy his curiosity, by studying the Qur'an himself. After a long search, he found enlightenment when he arrived at an understanding of the 'right path' (sirāṭ al-mustaqìm [Q 1.6]; Muis, Abdussalam, and Cahya 2017b, 4). His and Mahful's works stress how important it is to find the right path to approach religion. For Mushaddeq, the right path consists not of performing rituals, such as prayers five times a day or fasting during the month of Ramadan, as most Muslims understand it, but rather of finding a true understanding of the role religion can play in society.

In 2001, he founded an Islamic group called Qiyadah Islamiyah. The Qiyadah was successful in attracting followers and the membership grew to more than 41,000, spread across many provinces of Indonesia (Komaruddin 2008, 36; Muhsonef 2008, 24). ${ }^{3}$ Cak Momo, an important Qiyadah leader, estimates the number at as many as $58,000 .^{4} \mathrm{In}$ its early stages, the Qiyadah, like many other religious groups in the archipelago, was simply an Islamic group concerned with the many important moral duties of Muslims, with a particular focus on understanding and contextualizing Islam in the current 
Indonesian situation. The group advocated the reform of Islam by offering a more contextualized interpretation of the Qur'an, appropriate for modern circumstances. Indonesia has a long tradition of reciting the Scripture as a vital part of prayers and rituals, in which recitation may become merely an art (Denny 1989; Rasmussen 2001, 2005), but the group's followers are critical of the many Muslims who recite the Qur'an without understanding its meaning.

However, in 2006 Mushaddeq declared himself to be a Messiah and prophet. He asked his followers to accept his claim and testify: 'There is no God but God and the Messiah (Mushaddeq) is the messenger of God.' For him, Islamic rituals, such as prayers and fasting, are not obligatory for as long as the government of Indonesia remains infidel (Majelis Ulama Indonesia 2016), since Indonesia's secular system is incompatible with the Islamic system that the Qiyadah wants to establish. For Mushaddeq, any Muslims who live under the rule of an infidel government, such as the Indonesian government, are not obliged to perform Islamic rituals. This idea attracted media attention and was considered a threat to the Islamic orthodox establishment in the country. Due to this claim, the MUI branded the Qiyadah as deviant (sesat), and demanded that the government of Indonesia disband the group and outlaw its teachings (Majelis Ulama Indonesia 2011). This led to the persecution and prosecution of Qiyadah leaders and members, and public controversy over Mushaddeq's prophethood and his teachings continues to today.

The second important proponent of Milah Abraham after Mushaddeq is Mahful Muis. He has two other pen-names: Mahful M. Hawary and Mahful Muis Tumanurung. He was born in Tonasa Sulawesi on 14 July 1975. Unlike Mushaddeq, who has no formal religious education, Mahful was educated in religious institutions from elementary to university level. He went to a traditional boarding school run by DDI (Dewan Dakwah Islam/ Islamic Call Council) in Mangkoso Sulawesi from elementary to high school. He earned a BA and MA from IAIN (Institut Agama Islam Negeri/Islamic State Institute) Syarif Hidayatullah, which later became UIN (Universitas Islam Negeri/Islamic State University). At the time when I interviewed him in Cipinang prison, Mahful was still finishing his dissertation for that university. He also still serves as a lecturer at the UIN Alaudin Makasar and STAI (Sekolah Tinggi Agama Islam/Islamic High Education) DDI Pangkep, Sulawesi. While studying for his BA, he was the head of the students' senate in 1998-1999. In many religious groups founded by Mushaddeq such as Qiyadah Islamiyah, Komar and Gafatar, Mahful has always played a critical role in management and leadership (Muis, Abdussalam, and Cahya 2017b, 1-2). In 2017, both men were sentenced to five years' imprisonment and I met and interviewed them in Cipinang prison. Whereas in the eyes of his followers Mushaddeq is a charismatic spiritual leader, Mahful has extensive knowledge of theology and history of religions. The combination of the two has been effective in attracting followers and managing the organization. We now turn to the development of the group under its many names.

\section{Transformations of the group}

According to his own testimony, after 40 years of searching for religious truth and spirituality, joining many Islamic organizations, and meeting many religious leaders and scholars, Mushaddeq found the 'truth' by himself, after which he founded the Qiyadah, attracting thousands of members across the Indonesian archipelago. The organization is 
well managed and has a systematic structure and recruitment process. It uses a multi-level marketing strategy. The organization's many levels, its board and organizing committees are well defined, each with its specific tasks and responsibilities. From the lowest to the highest level, each has a specific name and a leader entrusted with specific duties and authority. Meetings are held regularly in various cities. To meet the members of the Qiyadah, Mushaddeq often visited Medan, Yogyakarta, Padang, Batam and Makasar, where the number of the members grew. ${ }^{5}$

From 2001 to 2006, the Qiyadah's teaching had a modernist Islamic tendency aimed at the purification of Islam. ${ }^{6}$ The followers of the Qiyadah were called upon to consistently adhere to Islamic theology and observe Islamic teachings. ${ }^{7}$ In a booklet published in 2002, they are repeatedly reminded to honour the doctrine of tawhid (the oneness of God) (Mushaddeq 2007a, 32) and perform Islamic prayers (35), and women are told to wear Islamic dress (such as the hijab) (39). Every member of the Qiyadah was also asked to declare a mithāq (contract or vow), promising to heed the advice of, and be guided by, senior members or leaders assigned by the Qiyadah board (Katib [Ahmad Mushaddeq] 2006, 96; Mushaddeq 2007b). At this stage, the Qiyadah had a vibrant Islamic mission $\left(d a^{c} w a\right)$, like many other modernist Islamic organizations in the country.

A change of direction took place in 2006, however, after Mushaddeq received enlightenment and declared himself a Mahdi (Messiah) and crowned himself with a new title Abdussalam Messi (servant of peace and the Messiah). All members of the Qiyadah were asked to declare allegiance before the Mahdi and state: 'There is no god but God, and the promised Mahdi is the messenger of God.' The simple testimony to the prophethood of Mushaddeq also led to a change in the rituals among the Qiyadah's members. Islamic prayers and fasting during the month of Ramadan are no longer obligatory for members, ${ }^{8}$ who are required instead to perform night prayers and șadaqa (almsgiving). In addition, they believe in the mission brought by the Mahdi to transform their society in order to live and achieve a divine goal and they hold to that mission's ideal values. During this stage, they believed that they had an important divine duty, that is $d a$ ' wah jahran (public mission), by which they mean to recruit more members and spread divine messages of reformation in society. Their final goal is to establish the umm al-qurā, the capital city of Islam in Indonesia, in emulation of the Medina city-state founded by the Prophet Muhammad in the seventh-century in the Hijaz. Mahful has argued on many occasions that God still sends messages to human beings and he rejects the conventional interpretation of khätam according to which Muslims firmly hold that Muhammad is the last prophet, and no prophet will come after him. According to Mahful, 'The gate of prophethood and messengerhood remains open after Muhammad, an [open] prophethood which will bring the second version of Madinah al-Munawwarah into life, that is the Islamic caliphate' (Hawary 2009, 133). Since Mushaddeq's declaration that he is the Mahdi, according to members of the Qiyadah, the world has fallen into darkness. When the glorious caliphate of Baghdad was destroyed by the Mongols in the thirteenth century, the Islamic caliphate ended. The caliphate should be re-established in Indonesia in order to carry out the mission of divine truth. Mushaddeq believes that the Ottoman Turkish caliphate never represented the succession of Islamic power after the Abbasids. In fact, Mushaddeq recalls that colonialism and imperialism prevailed in the Muslim world for centuries. Now it is time to awaken the community of believers (umma) and to make Nusatara (the archipelago of Indonesia) the capital and centre of Islamic power. ${ }^{9}$ 
The Qiyadah movement attracted students in many cities. However, this sparked controversy in Indonesia, as Islamic orthodoxy during the reform period was growing robustly. Various media, including newspapers, magazines, television and the Internet, spread the news about the establishment of a new religion by a new prophet from Jakarta (Zainuri 2008). In 2007, the MUI responded by issuing a religious edict (fatwā) from the MUI's office in Yogyakarta, as the movement had recruited thousands of university students there and the city had become an important centre of Qiyadah activity (Muhsonef 2008). The national board of the MUI strengthened the Yogyakarta fatwa, which branded the Qiyadah as deviant. The MUI also called on the government to disband the group (Majelis Ulama Indonesia 2011). This fatwa motivated angry mobs in many cities of Indonesia to persecute the group and the police in many cities put Qiyadah members under surveillance. In Yogyakarta, some Qiyadah leaders were interrogated, while Mushaddeq went to a police office in Jakarta for his own safety. In 2008, he was tried in South Jakarta under the 1965 blasphemy law and was sentenced to four years in jail, but this was reduced to two-and-a-half years following an appeal to the High Court (Muis, Abdussalam, and Cahya 2017b, 5). While Mushaddeq was under arrest and in jail, some leaders and members were forced by the MUI to recant and return to mainstream Islam.

Meanwhile, Mahful was actively encouraging the remaining members of the Qiyadah to change its name to Komar (Komunitas Milah Abraham/Religion of Abraham Community), which it did in 2009. In the late Qiyadah period, the members had mostly been asked to believe in Mushaddeq as the Mahdi, Messiah and prophet, but then, during the Komar period, Mushaddeq and Mahful called on them to return to the religion of Abraham. Mushaddeq took the role of spiritual advisor, but was not directly involved in the management and leadership of the organization (Muis, Abdussalam, and Cahya 2017b, 5).

In 2011, the group took another name: Gafatar (Gerakan Fajar Nusantara/Archipelagic Dawn Movement), still led by Mahful (Eks Pengurus Gafatar 2015, 1). In 2012, Mushaddeq's son, Andry Cahya, was involved in the leadership (Muis, Abdussalam, and Cahya 2017b, 6). Gafatar recruited a large number of members, who performed migration (hijrah) to many provinces of Indonesia, such as in Sulawesi, Nusa Tenggara and ultimately Kalimantan, to cultivate unused land. But this led to another controversy. The MUI issued another fatwa pinpointing the group as nothing but another transformation of the deviant Qiyadah (Majelis Ulama Indonesia 2016). In 2016, the government banned Gafatar (Kementrian Agama Republik Indonesia 2016) and the three leaders were brought to trial in East Jakarta on charges of blasphemy (Kejaksaan Negeri Jakarta Timur 2016). In March 2017, Mahful and Mushaddeq were each sentenced to five years in jail, and Cahya to three years.

\section{Returning to the religion of Abraham}

Since 2007, both Mushadddeq and Mahful have called upon their followers on many occasions to return to the root of the true religion sent by God to Abraham, which they called Milah Abraham. They argue that, since Abraham, God has communicated with messengers and prophets, to whom He sent true messages to guide human beings to the true path (al-sirät al-mustaqìm). According to Mushaddeq and Mahful, all prophets 
mentioned in the Bible and the Qur'an embraced, and called upon their followers to embrace, the religion of Abraham. Not only is the religion older than the traditions of Judaism, Christianity and Islam, but it is also the most inclusive, encompassing all three major Semitic religions. Furthermore, God appointed Abraham as the forefather of all prophets. ${ }^{10}$

Both Mushaddeq and Mahful allege that the three religions, Judaism, Christianity and Islam, have deviated from the true Milah and therefore have failed to address the problems currently facing humanity. According to Mushaddeq, ${ }^{11}$ Judaism today is nothing but a broken branch (cabang yang patah), by which he means that the people of Israel have gone astray. He emphasizes that the Jews are no longer committed to the principle of tawhid (oneness of God), the most important teaching of Abraham, and says that some Jews are committed to a merely human secular system of law and lordship, as the majority of them have embraced secularism (Hawary 2009, 152-153). Christians too have deviated from Abraham's true religion, as they hold the doctrine of trinity, not the oneness of God. Mahful contends that the theology of Christianity has deviated from Jesus's true teachings and argues that all the prophets, including Jesus and Moses, taught the Milah Abraham to their followers. Nowadays, however, Christianity follows the teachings of St Paul, who introduced various innovations, such as the doctrine of ancestral or original sin, and the divinity of Jesus (Hawary 2009, 178).

Islam and Islamic civilization, on the other hand, have declined and thus been mocked by non-Muslim nations in the same way as the Israelites were humiliated during the time of Nebuchadnezzar. Mushaddeq says:

Today the community of Muslims has fallen into darkness and has been mocked by other [non-Muslim] nations. The Muslims' fate is similar to that of the Israelites during the time of Nebuchadnezzar. Today we see that the Muslim community cries for help. (Katib [Ahmad Mushaddeq] 2006, 94)

Mushaddeq reinterprets the word sunnatullah (God's law), by which he means the tradition of God (tradisi Tuhan) (Muhdats [Ahmad Mushaddeq] 2007, 12-13). This tradition can be found in human history, when God sent numerous prophets or messengers to warn various peoples in various places at various times, whenever the people forgot the Milah Abraham. Mushaddeq goes further, saying that, throughout human history, the Milah Abraham and evil forces have always competed and the truth was not always victorious, with each taking turns to control human affairs for about 700 years. During the time of Abraham, for example, the arrogant and wicked king Namrudz/Nimrod ruled the world. Likewise, during the time of Moses, who restored the Milah Abraham, Pharaoh ruled the world. However, 700 years after that, the wise King Solomon ruled the people. History then changed. Those who followed the Milah Abraham were defeated and dominated by infidel rulers including Nebuchadnezzar of Babylonia, Koresh of Persia, Alexander of Greece and Herod of Rome. God then sent Jesus and Muhammad to reestablish the kingdom of God (khiläfa). However, followers of both those prophets transgressed God's law and committed sins, so God punished them by sending more wicked rulers, such as the Mongols who devastated the Abbasids and brought the dynasty down, and centuries of Western colonialism that caused suffering in the Muslim world. 
In the aftermath of colonialism, Mushaddeq believes that the Milah Abraham and God's kingdom should be reestablished nowhere but in the Indonesian archipelago. The Bible mentions some Israelite messengers, while the Qur'an adds some Arab messengers. Mushaddeq believes that Indonesia is also a place for prophets. Mushaddeq refers to God's messengers in Indonesia, such as Sabdo Palon Naya Genggong (1453-1478) ${ }^{12}$ and Ronggowarsito (1802-1873). ${ }^{13}$ He prophesies that the rise of Milah Abraham will take place in Indonesia, which will become the centre of civilization guided by God to His path. ${ }^{14}$

Mushaddeq and Mahful base their faith, theology and interpretation of human history and prophets on reading the Old and New Testaments and the Qur'an. Their conclusions challenge Islamic orthodoxy and the rise of conservatism in Indonesia. Many conservative Islamic groups have called upon Muslims to return to the two sources of Islam, the Qur'an and Sunna (Muhammad's tradition), but the two leaders of Milah Abraham quote numerous verses from both the Old and New Testaments. To explain the identity of Abraham, for example, they read the book of Genesis and other verses in the Old Testament. Likewise, in explaining Moses, Daniel and other Hebrew prophets, both refer to stories taken from the Scripture. Mushaddeq's knowledge of the Christian tradition is not surprising, as he was friend of Robert P. Walean from Menado, a minister of the Gereja Masehi Advent Hari Ketujuh (Seventh Day Adventist Church) who wrote a book about Milah Abraham (Walean 2006). They had intensive discussions at Walean's house in Jakarta. Walean also cited not only the Bible but also the Qur'an in explaining the term hanif or Milah Abraham. He explains the identity of Abraham, for instance, by reference to Q 16.123, Q 23.53, Romans 4.16 and Ezekiel 22.26-28 (8). Interestingly, Mushaddeq refers to the same biblical and qur'anic verses (Katib [Ahmad Mushaddeq] 2006, 13 and 19).

According to Mushaddeq, each prophet has a covenant (perjanjian) with God. Abraham has the oldest covenant, a contract between the prophet, God and his people. The most famous covenant is that of Moses, based upon which the First Temple was built in Jerusalem. But human beings forgot the true teaching of the covenant, and the city was destroyed. Afterwards, Mushaddeq writes, God sent Jesus, after whom the Second Temple was built. It seems that Mushaddeq's reading of history misunderstands the fact that the second temple was built in the sixth century BCE and destroyed after Jesus in $70 \mathrm{CE}$. Be that as it may, Mushaddeq continues that, like the First Temple, the Second Temple was also destroyed. God then sent Muhammad who successfully renewed the covenants of the previous prophets and messengers and built Darussalam/ the abode of peace (spanning from the time from the Medina of the Prophet to the Baghdad of the Abbasids). As Mushaddeq puts it:

The law of God will never cease until the end of Islamic glory [initially] built by the Prophet Muhammad [lasting until] the thirteenth century CE. According to the law of God, the struggle between His kingdom and that of evil, the world of peace and that of wickedness, truth and falsehood, light and darkness, never ceases. As such it will continue into the next thousands or millions of years. (Messi [Ahmad Mushaddeq] 2011, 552-553)

However, the people of the prophets forgot these covenants. Jews, Christians and Muslims have gone astray and forgotten the true teachings of the religion of Abraham. Mushaddeq likens the backwardness and moral decadence of people today to living in a hell. Muslims today are being left behind by the more developed Western world and are morally corrupt, because the Muslim world has deviated from the true religion of Abraham, and this has 
prevented Muslims from progressing or being able to compete economically with the Western world. Mushaddeq remarks:

We are talking about the Muslim community; if there is a Muslim who becomes smart and successful, it is only a personal achievement and is not caused by his Islamic theology. In fact, the Muslim community today everywhere is a subject of ridicule and mockery in the world, a symbol of backwardness and stupidity, and is seen as a latent danger [to the world order]. However, both the Christian and Jewish communities have also gone astray. (Muhdats [Ahmad Mushaddeq] 2007, 169).

Mushaddeq goes further and claims that when the Darussalam/abode of peace (Baghdad) was destroyed, Islamic authority (the caliphate) disappeared and Muslim leaders failed to return to the religion of Abraham. During colonial times, Western rulers arrested and jailed these leaders. The crisis hampering most of the Muslim world today, Mushaddeq argues, is that God also has annulled the spirit of the Qur'an. A thousand years after the destruction of Islamic civilization and the fall of Baghdad, the Abbasid capital, the spirit of the Qur'an has expired. ${ }^{15}$ Mushaddeq believes that he has been sent by God as the Messiah, whose duty is to call upon all the people of the world to return to the covenant of Abraham. Through this divine task, he will restore not only Islam but also the teachings of Jesus, Moses and, ultimately, Abraham. He says:

The task of the Messiah is to restore Jerusalem, which should become the light of God, a just city, where the house of God on Mount Sion above all mountains of all nations [was established], as was done by Jesus Christ. (Muhdats [Ahmad Mushaddeq] 2007, 80)

In 2007, after meditating for 40 days on the hill of Bunder near Bogor, Mushaddeq received God's revelation. Momo told me that during that time Mushaddeq built a hut in the middle of a rice field to avoid the crowds by withdrawing (tahannuth). Food and drink were sent to him regularly. ${ }^{16}$ Both Mushaddeq and Momo told me that the Prophet Muhammad practised this tahannuth in the cave of Hira, after which he was appointed as a God's messenger. Similarly, after performing this ritual, Mushaddeq was appointed as a Messiah and messenger of God in the same way as Muhammad, Jesus, Moses and Abraham. Mushaddeq's main mission is to restore both God's religion and civilization and to guide human beings to the true path. He states:

During my contemplation on the hill of Bunder, I received many revelations from God, which I am delivering to you all. All advice that you have learned from me should be heeded and obeyed; and you should therefore testify that all is truth coming from God through His messenger. (Muhdats [Ahmad Mushaddeq] 2007, 184)

In claiming divinity and prophethood, Mushaddeq seeks legitimacy through his interpretation of the Old and New Testaments and the Qur'an. One of his most important teachings is belief in his own prophethood. On this he states:

Thus, the awaited Messiah will rely on the Qur'an as a means to pave the way to the right path, and all believers should follow the awaited Messiah, because he receives knowledge of the Qur'an (revelation) from God. He will lead human beings under the guidance of the Qur'an consistently. (Muhdats [Ahmad Mushaddeq] 2007, 187)

During the early period of the Qiyadah, the mission for most followers was carried out in clandestine ways ( $d a^{c} w a$ sirran). In the next phase of the mission, dac wa jahran (declaration of the mission in public) took place, which included the declaration of the promised 
Messiah (al-masih al-maw' $\bar{u} d)$ in public. The most important teaching in the third phase is hijra (migration) to other lands in order to establish umm al-qurā (the capital city of the caliphate) and the madina munawwara (the city that shines), which will become the centre of world civilization (Muis, Abdussalam, and Cahya 2017a, 99-111). What Mushaddeq means by the centre of civilization is Nusantara (the Indonesian archipelago). Under the new organization, Gafatar, he called upon his followers to find and purchase land in the archipelago where he would turn the mission of establishing the umm al-qurā into reality. The followers of Gafatar then implemented this call by migrating to Papua, Sulawesi, Nusa Tenggara, and finally to Kalimantan. However, the government was suspicious of any possible clandestine plan to rebel against the government, so they were expelled from many of these places. From Kalimantan they were sent back home to Java and Sumatra. Their leaders were further investigated and some were arrested (Eks Gafatar 2017).

Mushaddeq and Mahful believe that the people of Nusantara are the descendants of Abraham and his third wife Kentura, ${ }^{17}$ who established various kingdoms in the archipelago: Tarumanegara in Banten, ${ }^{18}$ Kandis ${ }^{19}$ and Melayu in Jambi, ${ }^{20}$ Sriwijaya in Palembang, ${ }^{21}$ Tulang Bawang in Lampung, ${ }^{22}$ Perlak $^{23}$ and Samudera Pasai in Aceh, ${ }^{24}$ Panjalu, ${ }^{25}$ Singasari $^{26}$ and Majapahit ${ }^{27}$ in East Java, Demak and Mataram in Central Java, Wajo and Goa-Tallo in South Sulawesi, Ternate, and the sultanates of Solo and Yogyakarta. ${ }^{28}$ Mushaddeq asserts that colonial and modern historians hide these accounts by manipulating the history of Nusantara. For Mushaddeq, Majapahit, and all of the above-mentioned kingdoms, were not Hindu kingdoms as historians claim, but kingdoms that honoured the religion of Abraham and followed the path of the biblical and qur'anic prophets (Muis, Abdussalam, and Cahya 2017a, 156).

Mushaddeq believes that his prophetic mission is to awaken the Nusantara for the next generation. Another prophecy he made is that his prophetic mission would be accomplished in $2024 .{ }^{29} \mathrm{He}$ also believes that he is a messenger from God not only for Indonesians but also for the whole world with its centre in Nusantara, which will succeed Baghdad's caliphate in ruling the world. Mushaddeq also recalls that Nusantara was glorious in the past, with its high point during the kingdom of Majapahit. After its fall the archipelago was ruled by Dutch, British and Japanese colonial governments. He believes that it is time to rise up and establish the glory of Nusantara once more for the rest of the world (Muis, Abdussalam, and Cahya 2017a, 160-161).

\section{A new syncretism and its contribution to Indonesian Islamic pluralism}

The rise of Gafatar with the idea of returning to the religion of Abraham contributes to another dimension to the plurality of Indonesian Islam. Since the 1960s, many researchers have seen the potential of the pluralism found in many local practices of syncretism, referring to the way in which Islam and local cultures and traditions meet and mingle (Geertz 1960, 1968, 1983; Hefner 1985; Makin 2016d). ${ }^{30}$ Islam in Java, for example, features some unique syncretic practices, such as ways of sharing in a communal meal (slametan) (Woodward 1988; Beatty 1996; van den Boogert 2017). Islam has interacted with and assimilated some elements of Hinduism and Buddhism, which came to the archipelago before Islam (Makin 2016c). Islam's assimilation and accommodation of Hindu and Buddhist elements can be seen in various architectural styles of mosques in Java, such as 
Kudus or Demak (Budi 2004; Roesmanto 2013; Sucitra 2015; Supatmo 2016). In addition, various genres of Javanese literature, such as serat (letter) and babad (chronicle), contain some indications of the Islamization of Hindu and Buddhist traditions (Makin 2016d). Other islands in the archipelago present other examples of syncretism between Islam and unique local cultures, such as Lombok island with its wetu telu Islamic tradition, which incorporates the Hindu-Buddhist and traditional culture of Sasak, a local ethnic tradition in the island. The followers of the wetu telu pray three times a day instead of five, as indicated in its name wetu telu (three times). Nor do they fast the whole month of Ramadan, but only three days. This practice is marginalized, however, because of the strong wave of Islamization in the archipelago (Budiwanti 2000). In addition, Indonesia is home to hundreds of local religions, which the government calls aliran kepercayaan (sects), and which have also developed various syncretic practices with parts of 'official' religions and local beliefs and traditions (Makin 2016a, 2017b). However, the Milah Abraham as taught by Mushaddeq and Mahful presents a new attempt to combine Islam, Christianity and Judaism.

Mushaddeq's and Mahful's attempt to accommodate two older religious traditions, however, remains textual, based on verses of the Old and New Testaments. They do not have any knowledge, experience or involvement with particular Christian churches or Jewish traditions. Apart from reading the two Testaments, they have both only met with one Christian minister to learn about Christianity, and they fail to mention any Jewish rabbi, as there is no visible presence of Judaism in Indonesia. All in all, their attempt to accommodate the two older religions may be seen as a new model of syncretism.

However, the combination of Islam, Christianity and Judaism through reading the Old and New Testaments is not entirely new in the archipelago. The Malim religion in Sumatra, which emerged in the early twentieth century, exhibits this accommodation in its theology, rituals and prayers (Makin 2016a, 146-150, 2017b, 217-224). In addition, the Malims continue to embrace Batak local culture. It can be argued that the religion of Abraham as proposed by Mushaddeq is a step forward, as both Mushaddeq and Mahful read and quote the Bible and the Qur'an throughout their arguments in defence of Mushaddeq's prophethood and they give accounts of some prophets based on the Old and New Testaments and the Qur'an. It is noteworthy that, after the reform period, the two NRMs that have been the most successful at surviving and recruiting members are Salamullah led by Lia Eden and Gafatar led by Mushaddeq. Interestingly, both movements clearly include some elements of other Scriptures in their theological positions. Compared to Mushaddeq, Lia accommodates more religious traditions, including Hindu, Buddhist and Chinese traditions (Makin 2016a). This model of syncretism was first introduced during the reform period.

It should be noted that some Indonesian intellectuals also promote the term Milah Abraham in their effort to promote tolerance between Christianity and Islam in the country. They aim at finding similar roots and historical legitimacy in the two religions in order to increase understanding and solidarity among the followers of both (Kersten 2016, 228 and 235; Munawar-Rachman 2010, 542; Sirry 2004, 17-61). However, the calls for a return to Milah Abraham by the intellectuals and by Mushaddeq are different. The intellectuals do not intend to incorporate the three religions into their theology or faith, whereas Mushaddeq boldly blends the three into a new faith. 
Mushaddeq's concept of Milah Abraham contributes to the understanding of religious pluralism in Indonesia. Since the New Order, progressive Indonesian Muslim scholars, including scholars in Yogyakarta and Jakarta, have related Indonesia's pluralism to secularism, tolerance and liberalism (Makin 2017c). They interpret 'pluralism' in at least three ways. First, the adherents of a religious tradition should appreciate the truth in other religions. Second, they teach inclusive theology, by which they preserve a place in their faith for the truth of other religious traditions. Third, the two ways should lead to interreligious dialogue and religious tolerance in Indonesia's pluralistic society (Kersten 2016, 225-228; Munawar-Rachman 2010, 523-541). However, the intellectuals do not dare to take the further step of accommodating other religious traditions within their own theology but keep them on the margins of their religious faith and theology. NRMs such as Gafatar have crossed this border, as Mushaddeq and Mahful clearly did when they included the wisdom of Christianity and Judaism in formulating the Milah Abraham. Generally speaking, NRMs have a tendency to offer religious syncretism and are more tolerant about taking in diverse elements of different religions (Mayer 2011). As Dawson (1998a, 139) puts it: '.. the new religious consciousness is remarkably more syncretistic, accepting of relativism, and tolerant of other religious perspectives and systems than the religions dominant in the West in the past'.

Furthermore, NRMs in Indonesia have a critical attitude towards Islamic hegemony, while criticism by Muslim intellectuals of their own religious tradition does not go outside the boundaries of their faith. NRMs are courageous in offering compromises between the conflicting theological differences between Christianity, Judaism and Islam, while conventional theologians and intellectuals are not. NRMs also offer another dimension of criticism in considering why and how Muslims remain behind followers other religious traditions. It is also noteworthy that NRM leaders have experience as both insiders and outsiders of Islam. Mahful, for instance, was an Islamic scholar and educated in pesantren, but since joining Mushaddeq and believing in Mushaddeq's messengerhood, Mahful has stepped outside Islam, or has simply apostatized. Likewise, Mushaddeq was a Muslim but, as he declares his prophethood, he too has apostatized from Islam. Muslim scholars are only insiders. Experiencing two different positions as outsiders and insiders gives Mushaddeq and Mahful more freedom to criticize Islam and offer alternative religious views on Islam. They are free to formulate the alternative solution of returning to the religion of Abraham, which is more primordial and inclusive than identifying with only one religious tradition, such as Islam.

The issue of identity is also shown in this call by Mushaddeq for a return to the religion of Abraham. After observing the emergence of some NRMs in the context of globalization and the modern world, Dawson asserts:

In the modern world identity is fragmented or at least pluralized. Either way, for many, having a meaningful identity at all has become problematic. In the face of this, so the argument runs, the proliferating new religions provide a holistic sense of self, in theory and in practice, that transcends the constellation of limited instrumental roles recognized by modern mass society. (Dawson 1998a, 137)

The current globalizing world has led the Muslim community to experience multiple identities in many modern nation states. Between the religious claim of Islamic universalism and local or regional identity, Muslims are faced with how to define themselves (Bowen 
1998; Hassan 2006). Progressive Muslim intellectuals, such as Abdurrachman Wachid and Nurcholish Madjid, stress the national identity of Indonesian Muslims, coining the term 'Indonesian Islam' (Majid 2008; Makin 2017c). This effort is also known as pribumisasi Islam (indigenization of Islam) (Wahid 1998; Baso 2002), which is also developing in the area of fiqh (Islamic jurisprudence) (Feener 2002; Muhtadi 2005) and tafsir (qur'anic hermeneutics) (Setiawan 2012). While Muslim intellectuals point out the importance of the Indonesian context and identity in interpreting Islam, Mushaddeq gives Indonesian identity priority over religious and spiritual experience. This can be seen in his emphasis on the greatness of Nusantara in the past. He aims to awaken the spirit of patriotism to recreate Indonesia's lost glory. For Mushaddeq, Nusantara will become the centre of world civilization and religious tradition, and a similar prophecy is made by Lia Eden (Makin 2016a).

\section{Notes}

1. By 'Islamic orthodoxy' I mean here conservative Sunni Islam in which many call upon Muslims to strictly follow Islamic norms. Islamic conservatism often comes with a call to return to the Qur'an and Prophetic tradition (Sunna) and to purge non-Islamic practices. In Indonesia, the MUI (Indonesian Ulama Council), founded in 1975, promotes and guards this orthodoxy. During the reform period, radical and conservative Islamist ideologies, such as the FPI (Islamic Front Defender), FUI (Islamic Community Forum) and HTI (Hizbut Tahrir of Indonesian), supported the stance of the MUI.

2. According to Riis $(2007,2)$, pluralism refers to 'a recognition of multiplicity in society and as a precondition for individual choice and freedom'. On the other hand, Bender and Klassen $(2010,8)$ define pluralism as an 'active seeking of understanding across lines of difference'. In Indonesia, pluralism is interpreted as 'an open, inclusivistic, liberal understanding of Islam' (Barton 1997, 344), an understanding that is promoted by Muslim intellectuals from Nurcholish Madjid to Abdurrahman Wahid (Makin 2016a, 12).

3. Information also gathered from my first interview with Giri. Yogyakarta, 13 March 2017.

4. Information gathered from my first interview with Momo. Jakarta, 30 January 2017.

5. Information also gathered from my second interview with Giri. Yogyakarta, 31 March 2017.

6. Two major organizations, Nahdlatul Ulama (NU) with a traditionalist tendency and Muhammadiyah with a modernist tendency, dominate the Indonesian Muslim community, despite the fact that many more conservative groups, such as FPI, PKS (Prosperous Justice Party) and HTI, played important public roles during the reform period. The traditionalist group has strong roots in traditional boarding schools (pesantren), whereas the modernists have established various modern schools, universities and hospitals. The modernists promote the purification and reformation of Islamic teachings, whereas the traditionalists preserves local culture. However, the modernists are now trapped in conservatism, while the traditionalists show more ideological openness.

7. Information gathered from my second interview with Momo. Jakarta, 4 February 2017.

8. Information gathered from my first interview with Giri. Yogyakarta, 13 March 2017.

9. Interview with Mushaddeq. Cipinang prison, Jakarta, 28 August 2017.

10. Information gathered from interviews with Mushaddeq and Hawary M. Cipinang prison, Jakarta, 28 August 2017.

11. Information gathered from an interview with Mushaddeq. Cipinang prison, Jakarta, 28 August 2017.

12. Sabdo Palon and Naya Genggong are two mythical figures in Javanese society, believed to be the guardians of Javanese culture. They appear in many fictional, spiritual and mystical works (Achmad 2011; Hadiluwih 2010; Hardiyanto 2006; Kresna and Parjiati 2012).

13. Ronggowarsito is a Javanese poet and mystic whose fame lies in his prophecy and social criticism of a 'crazy era/zaman edan'. His syncretism between Islam and Javanese culture has 
become the subject of many studies (Purwadi and Ranggawarsita 2004; Ruslan 2012; Simuh 1988).

14. Interview with Mushaddeq. Cipinang prison, Jakarta, 28 August 2017.

15. Interview with Mushaddeq. Cipinang prison, Jakarta, 28 August 2017.

16. Information gathered from my second interview with Momo. Jakarta, 4 February 2017.

17. Most Muslims believe that Abraham had two wives, Sarah and Hagar. Sarah gave birth to Isaac, who became the forefather of the Israelites, whereas Hagar delivered Ishmael, the forefather of the Arabs. However, Mushaddeq and Mahful refer to Genesis 25.1-6: 'Abraham had taken another wife, whose name was Keturah. She bore him Zimran, Jokshan, Medan, Midian, Ishbak and Shuah. Jokshan was the father of Sheba and Dedan; the descendants of Dedan were the Ashurites, the Letushites and the Leummites. The sons of Midian were Ephah, Epher, Hanok, Abida and Eldaah. All these were descendants of Keturah. Abraham left everything he owned to Isaac. But while he was still living, he gave gifts to the sons of his concubines and sent them away from his son Isaac to the land of the east' (Muis 2016, 43).

18. Tarumanegara was a fourth-century Hindu kingdom in Bogor, West Java. An inscription found in the Citarum River displays the footprint of King Purnawarman, who claimed to represent the god Vishnu.

19. No historical records or archeological evidence explain the existence of the kingdom of Kandis.

20. According to a Chinese source, the Buddhist monk Yijing of the Tang dynasty, the Melayu or Dharmasraya kingdom predated and was annexed by Sriwijaya.

21. This eighth-twelfth-century Buddhist kingdom has become a source of national pride and a symbol of Indonesian history predating Majapahit. The greatness and glory of the marine kingdom is presented in many history textbooks from elementary to university level.

22. Historical records and archeological evidence are too scarce to explain the existence of the Tulang Bawang kingdom.

23. This Perlak refers to the ninth-century sultanate of Peureulak.

24. This refers to the thirteenth-sixteenth-century Samudra Pasai sultanate on the north coast of Sumatra.

25. Panjalu may refer to either the twelfth-century Hindu kingdom in East Java or another thirteenth-century kingdom with the same name in West Java.

26. Singasari is a thirteenth-century Hindu-Buddhist kingdom in East Java, whose kings were revered and claimed to be the forefathers of the kings of Majapahit.

27. Mahapahit was the greatest Hindu-Buddhist kingdom in the archipelago of Indonesia in East Java and lasted from the thirteenth to the sixteenth century. In modern Indonesia, it serves as a symbol of national unity.

28. All of these names refer to various sultanates in the archipelago of Indonesia from the sixteenth to twentieth century.

29. Information also gathered from my second interview with Momo. Jakarta, 4 February 2017.

30. The term 'syncretism' in this article refers to the combination or blending of the practices of two or more religious traditions. Such syncretic practices are commonly found in many local religious traditions across Indonesia, and Javanese practices of Islam show this tendency. An illustration of syncretism is the partaking of slameten (communal meal) with some Arabic Islamic prayers and Javanese Hindu-Buddhist mantras.

\section{Acknowledgements}

I would like to thank the Institute of Research and Community Engagement (LPPM) at the State Islamic University (UIN) Sunan Kalijaga in Yogyakarta for supporting me with additional funding to do this research. I am thankful to my colleagues at the LPPM: Moh Soehada, Muhrison, Arif Maftuhin, Gunadi, Dandung, Isnanto, Syamsuddin, Rini, Nurhasanah, Intan, Ade, Lina and others, and in the Al-Jami'ah office: Saptoni, Euis Nurlaelawati, Ahmad Bunyan Wahib, Uzair Fauzan, Rezza Maulana, Sayyidah Aslamah; and to all the Gafatar leaders and members whom I 
interviewed for this article. Special thanks to Heru and Yudhistira for allowing me to be involved in a court trial of Mushaddeq, Mahful and Cahya, and for helping me to visit them in Cipinang prison. This article is also dedicated to the memory of Cak Momo, who passed away in 2017; from him, I learned a lot about Gafatar. I am also grateful for many valuable discussions with members of the ALMI (Indonesian Young Scientists Academy) and of the Faculty Development Fellowship of Religion and Society in Asia, including from the Indonesian Consortium for Religious Studies Yogyakarta; the Institute for Humanities and Social Science at the University of Hong Kong, and the Asian Center for Cross-Cultural Studies, Chennai, India. Part of this article was presented at the Annual International Conference on Islamic Studies (AICIS) organized by the Ministry of Religious Affairs of Indonesia, 20-23 November 2017. My thanks should also go to Professor Martha Beck of Lyon College for her generous help in improving my English and to Carol Rowe for her patience in giving me further advice.

\section{Disclosure statement}

No potential conflict of interest was reported by the author.

\section{Funding}

This work was supported by LPPM (Institute of Research and Community Engagement) Sunan Kaliajaga State Islamic University; The Ministry of Religious Affairs of Indonesia.

\section{References}

Achmad, Sri Wintala. 2011. Sabdo palon. Bantul: Araska.

Arifin, Saru. 2008. "Law Enforcement on Blasphemy Offense (Study Case on Lia Eden Community, Yusman Roy and Ahmadiyah)." Millah: Jurnal Studi Agama 7 (2): 1-17.

Barker, Eileen. 1999. "New Religious Movements: Their Incidence and Significance." In New Religious Movements: Their Incidence and Significance, edited by Bryan Wilson and Jamie Cresswell, 15-32. London: Routledge.

Barton, Greg. 1997. "Indonesia's Nurcholish Madjid and Abdurrahman Wahid as Intellectual Ulama: The Meeting of Islamic Traditionalism and Modernism in Neo-Modernist Thought." Islam and Christian-Muslim Relations 8 (3): 323-350.

Baso, Ahmad. 2002. Plesetan lokalitas: politik pribumisasi Islam. Jakarta: Diterbitan atas kerjasama the Asia Foundation [dengan] Desantara. http://books.google.com/books?id=H_7XAAAAMAAJ.

Beatty, Andrew. 1996. "Adam and Eve and Vishnu: Syncretism in the Javanese Slametan." The Journal of the Royal Anthropological Institute 2 (2): 271-288. doi:10.2307/3034096.

Bender, Courtney, and Pamela E. Klassen. 2010. "Introduction: Habits of Pluralism." In After Pluralism: Reimagining Religious Engagement, edited by Courtney Bender and Pamela E. Klassen, 1-28. New York: Columbia University Press.

Berger, Peter L. 2008. The Desecularization of the World: Resurgent Religion and World Politics. Washington, DC: Ethics and Public Policy Center.

Bowen, John R. 1998. “What Is 'Universal' and 'Local' in Islam?” Ethos (Berkeley, CA) 26 (2): 258261.

Budi, Bambang Setia. 2004. "A Study on the History and Development of the Javanese Mosque." Journal of Asian Architecture and Building Engineering 3 (1): 189-195. doi:10.3130/jaabe.3.189.

Budiwanti, Erni. 2000. Islam Sasak: Wetu Telu versus Waktu Lima. Yogyakarta: Diterbitkan oleh LKiS Yogyakarta bekerjasama dengan Yayasan Adikarya IKAPI dan Ford Foundation.

Burhani, Ahmad Najib. 2014. "Treating Minorities with Fatwas: A Study of the Ahmadiyya Community in Indonesia." Contemporary Islam: Dynamics of Muslim Life 8 (3): 285-301.

Dawson, Lorne L. 1998a. "Anti-Modernism, Modernism, and Postmodernism: Struggling with the Cultural Significance of New Religious Movements." Sociology of Religion 59 (2): 131-156. doi: $10.2307 / 3712077$. 
Dawson, Lorne L. 1998b. "The Cultural Significance of New Religious Movements and Globalization: A Theoretical Prolegomenon." Journal for the Scientific Study of Religion 37 (4): 580-595.

Denny, Frederick Mathewson. 1989. “Qur'ān Recitation: A Tradition of Oral Performance and Transmission.” Oral Tradition 4 (1-2): 5-26.

Eks Gafatar. 2017. Sejarah Singkat Kronologi Perjalanan Organisasi Kemasyarakatan Gerakan Fajar Nusantara Tahun 2011-2016. [Jakarta], n.p.

Eks Pengurus Gafatar. 2015. Sejarah Singkat Kronologi Perjalanan Penolakan Dan Pengusiran Beberapa Daerah di Indonesia Organisasi Kemasyarakatan Gerakan Fajar Nusantara Dari Tahun 2011-2015. [Jakarta], n.p.

Fealy, Greg. 2004. "Islamic Radicalism in Indonesia: The Faltering Revival?” In Southeast Asian Affairs 2004, 104-121. Cambridge: Cambridge University Press.

Feener, R. Michael. 2002. "Indonesian Movements for the Creation of a 'National Madhhab'." Islamic Law and Society 9 (1): 83-115. doi:10.1163/156851902753649298.

Feillard, Andrée, and Rémy Madinier. 2011. The End of Innocence? Indonesian Islam and the Temptations of Radicalism. Honolulu: University of Hawaii Press.

Fenwick, Stewart. 2014. "Yusman Roy and the Language of Devotion: 'Innovation' in Indonesian Islam on Trial.” Studia Islamika 18 (3): 479-529. doi:10.15408/sdi.v18i3.427.

Geertz, Clifford. 1960. The Religion of Java. Glencoe, IL: The Free Press.

Geertz, Clifford. 1968. Islam Observed: Religious Development in Morocco and Indonesia. New Haven, CT: Yale University Press.

Geertz, Clifford. 1983. Abangan, santri, priyayi: dalam masyarakat Jawa. Edited by Bur Rasuanto. Translated by Aswab Mahasin. Jakarta: Pustaka Jaya.

Hadiluwih, Subanindyo. 2010. Bayang-bayang wayang: Sabdo Palon-Naya Geggong, TogogMbilung, Cangik-Limboek. Medan: USU Press.

Hardiyanto, Sigit. 2006. Ramalan ghaib, Sabdo Palon Noyo Genggong. Solo: Kuntul Press. http:// catalog.hathitrust.org/api/volumes/oclc/71174102.html.

Hassan, Riaz. 2006. “Globalisation's Challenge to the Islamic 'Ummah'.” Asian Journal of Social Science 34 (2): 311-323.

Hawary, Mahful M. 2009. Teologi Abraham, Membangun Kesatuan Iman, Yahudi, Kriste Dan Islam. Jakarta: Fajar Madani.

Hefner, Robert W. 1985. Hindu Javanese: Tengger Tradition and Islam. Princeton, NJ: Princeton University Press.

Hefner, Robert W. 2008. “A Conservative Turn in Indonesian Islam? Genesis and Future." In Muslim Politics and Democratization in Indonesia, 33-50. Clayton, VIC: Monash Asia Institute.

Hefner, Robert W. 2010. "Religious Resurgence in Contemporary Asia: Southeast Asian Perspectives on Capitalism, the State and the New Piety." Journal of Asian Studies: Review of Eastern and Southern Asia and the Adjacent Pacific Islands 69 (4): 1031-1047.

Hosen, Nadirsyah. 2012. "Pluralism, Fatwa, and Court in Indonesia: The Case of Yusman Roy." Journal of Indonesian Islam 6 (1): 1-16. doi:10.15642/JIIS.2012.6.1.1-16.

Katib [Ahmad Mushaddeq]. 2006. Al Masih al maw'ud dan Ruhul Qudus dalam perspektif Taurat, Injil, Al Qur'an. Jakarta: Fajar Islam.

Kejaksaan Negeri Jakarta Timur. 2016. "Surat Dakwaan No. Reg. Perkara PDM-/ Jkt -TM/10/ 2016," October 21 [Official Court Ruling].

Kementrian Agama Republik Indonesia. 2016. "Surat Edaran Bersama Sekretaris Jendreal Kementrian Agama Republik Indonesia, Jaksa Agung Muda Inteeljien, Dan Direktur Jenderal Politik Dan Pemerintahan Umum Kementrian Dalam Negeri Republik Indonesia.” 3 March.

Kersten, Carool. 2016. Islam in Indonesia: The Contest for Society, Ideas and Values. London: Hurst. Komaruddin, Nasrul. 2008. Ahmad Musaddeq dan ajaran Al-Qiyadah Al-Islamiyah. Yogyakarta: Media Press.

Kresna, Ardian, and Misni Parjiati. 2012. Sabdo Palon dan Noyo Genggong: Dua manusia abadi penunggu bumi Jawa. Yogyakarta: Diva Press. 
Majelis Ulama Indonesia. 2011. "Fatwa Majelis Ulama Indonesia Nomer 04 Tahun 2007 Tentang Aliran Al-Qiyadah Al-Islamiyah.” In Himpunan Fatwa MUI Sejak 1975, 114-118. Jakarta: Sekretariat Majelis Ulama Indonesia.

Majelis Ulama Indonesia. 2016. “Fatwa Majelis Ulama Indonesia Nomor 6 Tahun 2016 Tentang Aliran Gerakan Fajar Nusantara (Gafatar).” Majelis Ulama Indonesia.

Majid, Nurcholish. 2008. Islam, Kemodernan, dan Keindonesiaan. Bandung: Mizan Pustaka.

Makin, Al. 2010. "Pluralism versus Islamic Orthodoxy: The Indonesian Public Debate over the Case of Lia Aminuddin, the Founder of Salamullah Religious Cult." In Social Justice and Rule of Law: Addressing the Growth of a Pluralist Indonesian Democracy, edited by Thomas J. Conners, 187206. Tembalang, Semarang, Central Java; New Haven: Faculty of Social and Political Sciences, Diponegoro University; Yale Indonesia Forum.

Makin, Al. 2015. "Revisiting Indonesian Public Reactions against Danish Cartoons Depicting Prophet Muhammad." Indonesian Journal of Islam and Muslim Societies 5 (2): 195-229.

Makin, Al. 2016a. Challenging Islamic Orthodoxy: Accounts of Lia Eden and Other Prophets in Indonesia. Dordrecht: Springer.

Makin, Al. 2016b. "Islamic Acehnese Identity, Sharia, and Christianization Rumor: A Study of the Narratives of the Attack on the Bethel Church in Penauyong Banda Aceh." Journal of Indonesian Islam 10 (1): 1-36.

Makin, Al. 2016c. Keragaman dan Perbedaan, Budaya dan Agama dalam Lintas Sejarah Manusia. Yogyakarta: Suka Press.

Makin, Al. 2016d. "Unearthing Nusantara's Concept of Religious Pluralism: Harmonization and Syncretism in Hindu-Buddhist and Islamic Classical Texts." Al-Jami'ah: Journal of Islamic Studies 54 (1): 1-30.

Makin, Al. 2016e. "Identitas Keacehan dalam Isu-Isu Syariatisasi, Kristenisasi, Aliran Sesat dan Hegemoni Barat.” ISLAMICA: Jurnal Studi Keislaman 11 (1): 113-134. doi:10.15642/islamica. 2016.11.1.113-134.

Makin, Al. 2017a. "Homogenizing Indonesian Islam: Persecution of the Shia Group in Yogyakarta." Studia Islamika: Indonesian Journal for Islamic Studies 24 (1): 1-32.

Makin, Al. 2017b. Nabi-Nabi Nusantara: Kisah Lia Eden dan Lainnya. Yogyakarta: Suka Press.

Makin, Al. 2017c. "'Not a Religious State': A Study of Three Indonesian Religious Leaders on the Relation of State and Religion.” Indonesia and the Malay World 45 (133): 1-22. doi:10.1080/ 13639811.2017.1380279.

Mayer, Jean-François. 2011. "The Alternative Religiosity Market: Visit to an Esoteric Fair." Alternative Spirituality and Religion Review 2 (1): 6-19.

McDaniel, June. 2010. “Agama Hindu Dharma Indonesia as a New Religious Movement: Hinduism Recreated in the Image of Islam." Nova Religio: The Journal of Alternative and Emergent Religions 14 (1): 93-111.

Messi [Ahmad Mushaddeq], Abdussalam. 2011. Memahami Makna Kerajaan Allah. Jakarta: Fajar Madani.

Muhdats [Ahmad Mushaddeq], Michael. 2007. "Ruhul Qudus Yang Turun Kepada Al Masih Al Maw'ud." Bacaan Khusus Bagi Orang Yang Percaya Kepada Kitab-Kitab Alloh. Jakarta: n.p.

Muhsonef. 2008. "Fatwa MUI DIY Tentang Aliran Al-Qiyadah Al-Islamiyah, Perspektif Hukum Islam.” BA thesis., UIN Sunan Kalijaga, Yogyakarta.

Muhtadi, Asep Saepulah. 2005. Pribumisasi Islam: Ikhtiar menggagas fiqh kontekstual. Bandung: Pustaka Setia.

Muis, Mahful. 2016. "Pidato Ketua Umum Gafatar Pada Pembukaan Rakernas III.” In Buku Putih (Materi Pembelaan), edited by Andry Cahya, and Abdussalam [Mushaddeq], 39-52. Jakarta: n.p.

Muis, Mahful, Abdussalam, and Andry Cahya. 2017a. "Pembelaan, Konsistensi Millah Abraham Sebagai Jalan Kebenaran Tuhan Yang Maha Esa." Takbir (Tim Advokasi Hak Kebebasan Berkeyakinan dan Beragama Indonesia Raya). Jakarta: n.p.

Muis, Mahful, Abdussalam, and Andry Cahya. 2017b. "Sebuah Pledoi, Mengadili Cita Dan Karsa Menjadikan Indonesia Mercusuar Dunia.” Takbir (Tim Advokasi Hak Kebebasan Berkeyakinan dan Beragama Indonesia Raya). Jakarta: n.p. 
Munawar-Rachman, Budhy. 2010. Reorientasi pembaruan Islam: Sekularisme, liberalisme, dan pluralisme, paradigma baru Islam Indonesia. Jakarta: Lembaga Studi Agama dan Filsafat (LSAF): Paramadina.

Mushaddeq, Ahmad. 2007a. "Maklumat Al Qiyadah Al-Islamiyah Nomer 1/4/2002 Tentang Pembersihan Diri Dari Budaya Musyrik.” In Keutamaan Enam Program Pengabdian Lengkap Dengan Maklumat Tentang Program Permbersihan Diri Dari Bduaya Musyrik, 29-50. Jakarta: Al Qiyadah al Islamiyah.

Mushaddeq, Ahmad. 2007b. "Mitsaq." In Keutamaan Enam Program Pengabdian Lengkap Dengan Maklumat Tentang Program Permbersihan Diri Dari Bduaya Musyrik, 49-51. Jakarta: Al Qiyadah al Islamiyah.

Purwadi, and Ranggawarsita. 2004. Ramalan zaman edan Ronggowarsito. Yogyakarta: Media Abadi.

Rasmussen, Anne K. 2001. “The Qur'ân in Indonesian Daily Life: The Public Project of Musical Oratory.” Ethnomusicology 45 (1): 30-57. doi:10.2307/852633.

Rasmussen, Anne K. 2005. "The Arab Musical Aesthetic in Indonesian Islam." The World of Music 47 (1): 65-89.

Ricklefs, M. C. 1981. A History of Modern Indonesia, c. 1300 to the Present. Bloomington: Indiana University Press.

Ricklefs, M. C. 2006. Mystic Synthesis in Java: A History of Islamization from the Fourteenth to the Early Nineteenth Centuries. Norwalk: EastBridge.

Ricklefs, M. C. 2007. Polarizing Javanese Society: Islamic, and Other Visions, c. 1830-1930. Honolulu: University of Hawaii Press.

Riis, Ole. 2007. "Modes of Religious Pluralism under Conditions of Globalization.” In Democracy and Human Rights in Multicultural Societies, edited by Matthias Koenig and Paul de Guchteneire, 251-266. Paris: UNESCO.

Roesmanto, Totok. 2013. “Rupa Bentuk Menara Masjid Kudus, Bale Kulkul Dan Candi.” JA! UBL 4 (1), http://jurnal.ubl.ac.id/index.php/ja/article/view/459.

Ruslan, Muksin. 2012. “Konsep Al-Wahdah Al-Wujud Dalam Pemikiran Ronggowarsito.” Media Akademika 27 (1). http://e-journal.iainjambi.ac.id/index.php/mediaakademika/article/view/141.

Setiawan, Mohamad Nur Kholis. 2012. Pribumisasi al-Qur'an: tafsir berwawasan keindonesiaan. Yogyakarta: Kaukaba.

Simuh. 1988. Mistik Islam kejawen Raden Ngabehi Ranggawarsita: suatu studi terhadap serat Wirid Hidayat Jati. Jakarta: Penerbit Universitas Indonesia.

Sirry, Mun'im A. 2004. Fiqih lintas agama: membangun masyarakat inklusif-pluralis. Jakarta: Yayasan Wakaf Paramadina bekerjasama dengan the Asia Foundation.

Sucitra, I. Gede Arya. 2015. “Transformasi Sinkretisma Indonesia dan Karya Seni Islam.” Journal of Urban Society's Arts 2 (2): 89-103.

Supatmo, Supatmo. 2016. "Keragaman Seni Hias Bangunan Bersejarah Masjid Agung Demak." Imajinasi : Jurnal Seni 10 (2): 107-120.

van den Boogert, Jochem. 2017. "The Role of Slametan in the Discourse on Javanese Islam." Indonesia and the Malay World 45 (133): 352-372.

Wahid, Abdurrahman. 1998. Tabayun Gus Dur: Pribumisasi Islam, hak minoritas, reformasi kultur. Yogyakarta: LKiS.

Walean, Robert. 2006. Alkitab Menubuatkan Islam Hanif Akan Masuk Surga. Jakarta: Last Events Duty Institute.

Woodward, Mark. 1988. "The "Slametan": Textual Knowledge and Ritual Performance in Central Javanese Islam.” History of Religions 28 (1): 54-89.

Woodward, Mark. 1989. Islam in Java, Normative Piety and Mysticism in Teh Sultante of Yogyakarta. Tucson: University of Arizona Press.

Woodward, Mark. 2011. Java, Indonesia and Islam. Dordrecht: Springer.

Zainuri, Muhammad. 2008. "Framing Pemberitaan Tentang Al-Qiyadah Al-Islamiyah Di Surat Kabar Republika Dan Koran Tempo.” BA thesis., Sunan Kalijaga State Islamic University, Yogyakarta. 